\author{
Dori Laub \\ Johanna Bodenstab
}

\title{
Dwadzieścia pięć lat później. \\ Powrót do świadectw \\ ocalałych z Holokaustu ${ }^{1}$
}

\author{
Wrocławski Rocznik \\ Historii Mówionej \\ Wydanie specjane, 2018 \\ ISSN 2084-0578 \\ DOI: 10.26774 /wrhm.223
}

\section{Wstęp}

Niniejszy esej powstał dzięki naszemu udziałowi w wywiadach prowadzonych z ocalałymi z Holokaustu w ramach projektu dokumentującego pracę przymusową i niewolniczą $\mathrm{w}$ okresie nazizmu. Jednym $\mathrm{z}$ ważnych celów naszego podprojektu było odnalezienie ocalałych, z którymi Dori Laub przeprowadził wywiady pod koniec lat 70. i w latach 80 . XX w. ${ }^{2}$ dla mającego powstać Fortunoff Video Archive przy Uniwersytecie Yale ${ }^{3}$, oraz analiza porównawcza tamtych wczesnych świadectw z nowszymi nagraniami.

Tłumaczenie za: D. Laub, J. Bodenstab, Twenty-five Years Later: Revisiting Testimonies of Holocaust Survivors, [w:] Hitler's Slaves. Life Stories of Forced Labourers in Nazi-Occupied Europe, red. A. Plato, A. Leh, Ch. Thonfeld, New York-Oxford 2010, s. 426-44o. Zgoda na publikację przetłumaczonej wersji artykułu została udzielona przez wydawnictwo Bergham Books. Licencja CC BY-SA 4.o (przyp. red.).

Knowing and Not Knowing the Holocaust, red. D. Laub, N.C. Auerhahn, „Psychoanalytic Inquiry”, 5 (1/1985), s. 164-189; D. Laub, N.C. Auerhahn, Failed Empathy: A Central Theme in the Survivor's Holocaust Experience, „Psychoanalytic Psychology”, 6 (1989), s. 377-40o. Zob. także: D. Laub, Testimonies in the Treatment of Genocidal Trauma, „Journal of Applied Psychoanalytic Studies”, t. 4 (1/2002), s. 63-87.

3 Guide to the Yale University Library Holocaust Video Testimonies, red. Fortunoff Video Archive for Holocaust Testimonies, New Haven 1994. 
240 Niestety, wraz z upływem czasu odnalezienie wcześniejszych rozmówców stawało się coraz trudniejsze. Wielu z nich zmarło lub wyprowadziło się, aby być pod opieką dzieci, albo są w tak złym stanie zdrowia, że nie mogą udzielić kolejnego wywiadu. Ostatecznie wśród dwadzieściorga ocałałych, z którymi przeprowadzono wywiady jesienią $2005 \mathrm{r}$. oraz na początku wiosny 2006 r., znalazło się ośmioro, którzy już wcześniej przekazali Doriemu Laubowi swoje świadectwo ${ }^{4}$.

Kiedy szukamy przesunięć i różnic pomiędzy tymi dwiema grupami wywiadów zebranych w odstępie ponad dwudziestu pięciu lat, wyodrębnić możemy trzy główne obszary porównawcze, w których widać znaczące zmiany. Pierwszym z nich jest świadomość Holokaustu. W nowszych wywiadach wiele odwołań wyraźnie wskazuje, że w ostatnich trzydziestu latach w Stanach Zjednoczonych nastapiła duża zmiana w świadomości społecznej na temat Holokaustu. Zmiana ta nie tylko zapewnia kontekst społeczny dla narracji ocalałych, który wcześniej w sferze publicznej nie istniał, ale wpłynęła także na ich zdolność dawania świadectwa poprzez potwierdzenie ich tożsamości jako ocalałych i jako świadków historii.

Druga różnica dotyczy biografii. Te dwa zbiory świadectw powstały na dwóch różnych etapach życia rozmówców. W późnych latach 7o. i na początku lat $8 \mathrm{o}$. XX w. rozmówcy mieli ustaloną pozycję zawodową lub biznesową, a ich dzieci były w koledżu lub szykowały się do opuszczenia domu, aby studiować. Dziś są oni emerytami, mają dorosłe dzieci, a najczęściej i wnuki. Wydaje się, że ich zdolność relacjonowania przeszłości zmieniła się z wiekiem. Co zaskakujące, w większości przypadków wspomnienia nie zatarły się z upływem czasu lub z powodu związanej z wiekiem utraty pamięci. Jedynie Sidney G. pogubił się w kolejności obozów, w których był więziony, co stało się dla nas wszystkich oczywiste pod koniec wywiadu, kiedy przyglądaliśmy się dokumentom, które przyniósł. Wydaje się raczej, że przeszłość jest w naszych rozmówcach żywsza teraz niż wtedy, gdy po raz pierwszy przeprowadzaliśmy z nimi wywiady. Zmiana ta jest szczególnie

Wcześniejsze wywiady Evy B. (sygn. HVT-1), Leona W. (sygn. HVT-2), Shifry Z. (sygn. HVT-11), Helene R. (sygn. HVT-15), Zoltana G. (sygn. HVT-35), Sidneya G. (sygn. HVT-38), Ralpha E. (sygn. HVT-110) i Leo G. (sygn. HVT-158) są dziś w depozycie Fortunoff Video Archive przy Uniwersytecie Yale i zostały nagrane w ramach „Holocaust Survivors Film Project”. Wcześniejsze wywiady z Josephem K. (sygn. HVT-61) i Zahavą S. (sygn. HVT-301) również znajdują się w Fortunoff Video Archive; świadectwa te nie zostały jednak zebrane przez Doriego Lauba. 
interesująca z psychoanalitycznego punktu widzenia, ponieważ może sugerować, że w trakcie swojego życia nasi rozmówcy osiągnęli wyższy poziom integracji swego bardzo często traumatycznego doświadczenia. Oczywiście ten trwający całe życie proces „przepracowywania” jest silnie związany ze zmianą społecznego „klimatu” otaczającego ocalałych, ale także wiele mówi o intensywności ich wspomnień i o emocjonalnej wytrzymałości większości z naszych rozmówców, żyjących z przerażającą przeszłością. Wywiad z Ralphem E. jest jedynym, który trzeba było przerwać w obawie, że jego emocjonalny wpływ na ocalałego będzie zbyt wielki.

Trzecim obszarem porównań jest dynamika samego wywiadu. Ponieważ obie grupy wywiadów były prowadzone przez tę samą osobę, możliwe jest zaobserwowanie zmiany czy nawet ewolucji techniki. Oczywiście rezultat wywiadu zawsze w dużym stopniu zależy od tego, jak bardzo prowadzący go potrafi zaangażować rozmówcę, zarówno zadając pytania, jak i słuchając. Jednak w nowszych wywiadach zmiennym tym towarzyszy przede wszystkim pojmowanie „świadectwa” jako narracyjnej formy przyjętej przez rozmówcę. Takiego rozumienia nie było w czasie pierwszych wywiadów wideo z ocalałymi z Holokaustu, ale rozwinęło się ono w ciągu wielu lat prowadzenia wywiadów, teoretyzowania i obserwacji.

W niniejszym eseju spróbujemy omówić bardziej szczegółowo te elementy zmiany, pojmowane przez nas w praktyce jako wzajemnie powiązane i nakładające się na siebie. Te narracyjne przesunięcia, które nastąpiły w ciągu minionych dwudziestu pięciu lat, nie mogą być przypisywane wyłącznie jednemu z tych czynników, ale powinny być rozpatrywane raczej jako konsekwencja złożonych zmian zachodzących nie tylko w otaczającym rozmówców społeczeństwie, lecz także w ich życiu, a nawet podczas sesji wywiadu, wraz z jego rozwojem.

\section{Przesunięcia narracyjne w kontekście ewoluującego dyskursu publicz- nego na temat Holokaustu}

Podczas gdy dwadzieścia pięć lat temu nasi rozmówcy wypowiadali się we względnej izolacji, dziś ich świadectwa pojawiają się w kontekście dużo szerszego dyskursu publicznego. Niemożliwe staje się rozstrzygnięcie, w jakim stopniu większa społeczna świadomość Holokaustu pomogła naszym rozmówcom w ukształtowaniu ich tożsamości jako ocalałych z Holokaustu oraz w jakim stopniu świadectwa ocalałych pomogły przede wszystkim zwiększyć tę społeczną świadomość Holokaustu. Można jednak z pewnością stwierdzić, że jedno wywarło wpływ na drugie. W czasie pierwszych 
242 wywiadów wideo nie istniały jeszcze takie instytucje, jak Holocaust Memorial Museum w Waszyngtonie czy Museum of Jewish Heritage w Nowym Jorku, akademickie ośrodki badawcze, takie jak Genocide Studies Program przy Uniwersytecie Yale czy Strassler Family Center for Holocaust and Genocide Studies przy Uniwersytecie Clark, nie mówiąc już o inicjatywach prowadzenia wywiadów na wielką skalę, takich jak Fortunoff Video Archive przy Uniwersytecie Yale lub Steven Spielberg's Shoah Foundation. Zainteresowanie wywołane przez takie instytucje skupia się nie tylko na Holokauście jako wydarzeniu historycznym, na paradygmacie ludobójstwa czy żydowskiej tragedii, ale także na samych ocalałych jako naocznych świadkach tej historii. Chociaż historycy nadal debatują nad znaczeniem świadectw ocalałych dla ich badań i historiografii Holokaustú, wiele szkół w Stanach Zjednoczonych, zarówno publicznych, jak i żydowskich, „nauczając Holokaustu", bazuje na osobistych relacjach ocalałych.

Rzeczywiście, kilkoro z naszych rozmówców wspomina, że są regularnie zapraszani, by przemawiać w szkołach (Helene R., Sidney G., Shifra Z., a także Joseph K.). Czerpią oni osobistą satysfakcję ze spotkań z młodymi ludźmi i wyrażają nadzieję, że może przyszłe pokolenia wyciągną wnioski z tych lekcji, aby już nigdy nie dopuścić do ludobójstwa. Wydają się przekonani, że relacjonując swoją przeszłość, wnoszą ważny wkład w przyszłość.

Podczas gdy historycy, tacy jak Raul Hilberg i Lucy S. Dawidowicz uważają świadectwa ocalałych za źródła niewiarygodne, Saul Friedländer, jako ocalały i historyk, umiejscawia swe prace pomiędzy historią i pamięcią. Zob. krótkie omówienie jego stanowiska w: J.E. Young, Between History and Memory: The Uncanny Voices of the Historian and Survivor, [w:] Passing into History, Nazism and the Holocaust beyond Memory. In Honour of Saul Friedländer on his Sixty-Fifth Birthday, red. G. Ne'eman Arad (wydanie specjalne „History and Memory: Studies in Representation of the Past”, 9 (1-20/1997)), s. 47-58. Podobnie: O. Bartov, Inside, Outside, „The New Republic", z 10 kwietnia 2002 r., oraz Ch.R. Browning, Nazi Policy, Jewish Workers, German Killers, Cambridge-New York-Melbourne 20oo, podjęli próbę stworzenia metodologii, która pozwoli im ujmować relacje ocalałych bez narażania się na nierzetelność badań. Zob. także przykładowe studium Jana T. Grossa, Neighbours: The Destruction of the Jewish Community in Jedwabne, Poland, b.m. 2002 (wydanie polskie: J.T. Gross, Sąsiedzi: Historia zagłady żydowskiego miasteczka, Sejny 2000 - przyp. red.) o zabójstwie Żydów z polskiego miasteczka Jedwabne. Zob. również bardzo sceptyczne omówienie dyskursów historyków i ocalałych w: A. Wieviorka, The Era of the Witness, Ithaka-London 2006, s. 96-144, która streszcza ewolucję świadomości Holokaustu w Stanach Zjednoczonych i towarzyszące jej dyskusje. 
W ten sposób dzięki zainteresowaniu innych ich doświadczenie nie tylko zyskuje na wartości, ale także jest mu nadawane zbiorowe znaczenie.

Możliwe, że zainteresowanie naszymi rozmówcami jako ocalałymi jest obecnie większe, ale wydaje się, że oni również bardziej zainteresowali się sobą jako ocalałymi. Shifra Z. jest w komitecie, który organizuje coroczne wydarzenia upamiętniające Żydów zamordowanych podczas Holokaustu i pomaga w utrzymaniu lokalnego pomnika Holokaustu w New Haven. Leon W. napisał pamiętnik, który jest wnikliwie badany, aby usytuować jego osobiste doświadczenie w obrębie historii łódzkiego getta. Eva B. została aktywnym członkiem lokalnego oddziału organizacji ocalałych dzieci. Martwią się oni, że wraz z ich odejściem Holokaust mógłby zostać zapomniany. Czują potrzebę zarejestrowania swojej historii. Chcą być częścią przyszłości, zapisać się na kartach historii, ale również mają potrzebę przynależności, która jest najlepiej zaspokajana w ich własnym towarzystwie. Wydaje się, że wśród ocalałych istnieje szczególna więź ukształtowana przez wspólne doświadczenie Holokaustu. Pod tym względem organizacje ocalałych, które przygotowują wydarzenia społecznościowe i wspólnotowe obchody świąt, służą jako system wsparcia i dają namiastkę rodziny. Z upływem lat stało się to ważniejsze, ponieważ ocalali mają gorzką świadomość, że należą do „wymierającego gatunku” i ich liczba maleje.

W pewnym stopniu zainteresowanie naszych rozmówców samymi sobą jako ocalałymi pojawia się z pewnością za sprawą ich dzieci i wnuków. W kontekście Holokaustu zwraca się uwagę na nieistniejące dwadzieścia pięć lat temu „Drugie Pokolenie”: w wielu przypadkach trauma rodziców została przekazana dzieciom i jest ponownie odtwarzana. Problem ten nie tylko przyczynił się do rozwoju ważnych badań neurobiologicznych (Rachel Yehuda) oraz literatury psychoanalitycznej ${ }^{6}$, ale także do twórczości artystycznej samych przedstawicieli Drugiego Pokolenia'. Niektórzy z naszych rozmówców próbowali chronić dzieci przed swoim doświadczeniem Holokaustu. Leo G. stwierdził, że bardzo obawiał się emocjonalnego wpływu, jaki na dzieci i wnuki mogło wywrzeć jego doświadczenie, i bardzo wahał się, czy je nim obciążać. Do dzisiaj zmaga się on z ponawianymi przez dzieci pytaniami, ponieważ nie jest pewny, czy będzie w stanie przekazać swoją

Generations of the Holocaust, red. M. Bergmann, M. Jucovy, New York 1990.

Zob.: A. Spiegelmann, Maus: A Survivor's Tale, New York 1986, oraz idem, Maus. A Survivor's Tale II: And Here My Troubles Began, New York 1991. 
244 historię i czy będą one w stanie go zrozumieć. Jednocześnie Zoltan G. przybył z jedną ze swoich córek i zdawał się nie mieć najmniejszych wątpliwości co do podawania w jej obecności bardzo szczegółowego opisu swojego trudnego doświadczenia w Auschwitz.

Oczywiste jest, że nasi rozmówcy stali się bardziej pewni siebie jako ocalali. Nie oznacza to jednak, że są bardziej swobodni i lepiej czują się ze swoją przeszłością niż w czasie pierwszych wywiadów. Jednak nie muszą już podawać w wątpliwość realności swojego doświadczenia Holokaustu. Świadectwo stało się powszechnie szanowanym, społecznym dyskursem, który trwa w osobistym głosie jednostki, wyruszającej w podróż w poszukiwaniu siebie. W nowszych wywiadach ten osobisty głos był jednak od czasu do czasu wypierany przez dyskurs historyczny. Pamięć osobistego doświadczenia była tłumiona przez nadrzędną narrację historyczną. Szczególnie dotyczy to wywiadu z Leonem W., który w trakcie pisania swojego pamiętnika najwyraźniej wykonał pokaźną ilość badań na temat historii łódzkiego getta. Czasami jego narracja była zestawieniem wiedzy, którą zdobył dzięki swoim badaniom oraz wiedzy wynikającej z jego doświadczenia. Innym razem nadrzędna narracja historyczna zdawała się funkcjonować jak tarcza, która trzymała jego osobistą pamięć na dystans. W takich momentach osoba prowadząca wywiad czuła, że należy sprawić, żeby Leon W. powrócił do swojej osobistej narracji. Wydawało się, jakby stale i na nowo trzeba było zdzierać ochronną powłokę, aby Leon W. mógł odnieść się do swojej przeszłości w sposób bardziej intymny, mniej ukształtowany przez dyskurs historyczny.

\section{Zmiany w życiu rozmówców i wpływ tych zmian na narrację}

Dotąd zajmowaliśmy się kwestią świadectwa i jej wpływem na społeczne i historyczne okoliczności, w których się pojawia. Jednak skoro świadectwo pojmujemy nie tylko jako wytwór jego czasów, ale także jako unikalną narrację o osobistym doświadczeniu, to również fakty biograficzne musimy postrzegać jako całość przyczyniającą się do narracyjnych przesunięć i zmian w kształtu narracji (gestalt) jako całości. Porównanie dwóch świadectw Leona W. przynosi najbardziej złożony przykład takich zmian. Pierwsze świadectwo Leona W., które uznaje się za drugi wywiad wideo ze wszystkich kiedykolwiek przeprowadzonych z ocalałymi z Holokaustu, trwało około godziny i jedynie powierzchownie dotykało większości aspektów jego doświadczenia, z niewielką ilością szczegółów. Pomija jego doświadczenie czterech lat w łódzkim getcie. Jedynym wspomnieniem 
w pełni wypowiedzianym jest głód, który przez te lata cierpiał, i to, do czego go to zmusiło: „W tamtych dniach jedynym uczuciem był głód”. W nocy wstawał i potajemnie odkrawał kawałek chleba z przydziału swojej siostry. Z perspektywy czasu trudno było mu uwierzyć, że był w stanie kiedykolwiek coś takiego zrobić i czuł się bezgranicznie winny. Z jego rodziny nikt nie przeżył, również siostra, którą okradał.

Jego nowszy wywiad trwał dwie i pół godziny. Wahał się, czy go udzielić z powodu osłabienia, a także z obawy, że jego pamięć może być niewiarygodna. Kiedy prowadzący wywiad Dori Laub celowo spróbował ponownie naprowadzić go na temat kradzionych racji chleba, Leon W. powiedział, że w rzeczywistości okradał matkę, ponieważ jako nastolatek był w stanie wmówić sobie, że rodzice są tak wytrzymali, że jego kradzież nie może im zaszkodzić: „Nic by im się nie stało”. Okazało się również, że podkradanie przydziału matki było najmniejszą z jego chlebowych kradzieży w getcie: nocami wyciągał świeżo upieczony dla mieszkańców getta chleb przez otwarte okna magazynu, w którym był odkładany, żeby ostygł. Kiedy ktoś dostrzegł, że chleb znika, z przodu okien wstawiono kraty. Leon musiał udoskonalić swoją technikę: do kija przymocował nóż, aby kroić bochenki, a potem wyciągać je po kawałku spomiędzy krat. Wyraźnie zaznaczył, że nie kradł tylko dla własnej korzyści, ale żeby nakarmić całą swoją rodzinę. Kiedy ostatecznie zaczął pracować w jednej z piekarni getta, zrobił sobie woreczek, który potajemnie napełniał mąką, aby na koniec zmiany przemycić ją z piekarni i przynieść matce do domu. Trwało to dopóty, dopóki go nie złapano. Po krótkim uwięzieniu został skierowany do gorszej pracy, jako Fäkalist, który w getcie sprzątał wychodki i przenosił ekskrementy na wysypisko.

Zmiany zarejestrowane w tych dwóch wywiadach wideo Leona W. są wręcz niezwykłe. Nastąpiło przesunięcie od siostry do matki; doświadczenie jego głodu jest dużo bardziej wyraziste; strategie, które wymyślał, aby zdobyć więcej jedzenia, są o wiele lepiej dopracowane w szczegółach i mniej skupione na nim samym. Wszystkiemu temu towarzyszy wyraźna zmiana stosunku ocalałego do własnych czynów. We wcześniejszym wywiadzie jego relacja nic o tym nie mówi i jest jakby ograniczana przez wstyd. Jednak w nowszym wywiadzie Leon W. odnosi się do siebie, jako złodzieja chleba, z satysfakcją i jest dumny ze swojego sprytu.

Dość prawdopodobna jest interpretacja tej znaczącej zmiany jako oznaki zmieniającego się społecznego stosunku do Holokaustu, który już komentowaliśmy. Podczas gdy w pierwszym świadectwie Leona W. opis siebie jako kogoś, kto został przez głód doprowadzony do ostateczności i okradał 
246 własną rodzinę, pozostaje wyrazem osobistej tragedii, w bardziej współczesnym świadectwie dużo mniej przejmuje się on swoim złodziejstwem, które jako część historii getta łódzkiego zostało przekształcone w akt oporu. Złodziej chleba stał się figurą historyczną i jako taka wyzwolił ocalałego z jego osobistego poczucia wstydu. Przed Leonem W. otworzyła się się nowa narracyjna wolność i może on znacznie obszerniej ukazać swoje złodziejstwo w getcie.

Jego większa świadomość dyskursu historycznego ma jednak oparcie także w badaniach, które przeprowadził podczas pisania swojego pamiętnika. Od czasu przejścia na emeryturę Leon W. miał więcej czasu na myślenie o swojej przeszłości. Jeszcze jednym z aspektów jego zaawansowanego wieku jest zdolność wspominania siebie jako młodego czowieka, którym już nie jest. Żadna z tych okoliczności nie miała miejsca pod koniec lat 70. XX w., kiedy Leon W. składał swoje pierwsze świadectwo. Wywiady przeprowadzone $\mathrm{z}$ nim $\mathrm{w}$ odstępie ponad dwudziestu pięciu lat pozwalają nam ujrzeć tę samą osobę na różnych etapach życia. Ogólnie rzecz biorąc, dotyczy to wszystkich naszych rozmówców: od czasu złożenia pierwszych świadectw przybliżyli się do starości. Oznacza to również, że ich sytuacja rodzinna uległa zmianie. Dzieci są dorosłe, pojawiło się nowe pokolenie wnuków, a niektórzy (Helen R., Eva B.) po trwających całe życie związkach małżeńskich stracili swoich partnerów. Mamy wrażenie, że te zmieniające się okoliczności biograficzne zaważyły na sposobie, w jaki nasi rozmówcy odnoszą się do swojej przeszłości.

Różnica ta ujawnia się w narracyjnym kształcie ich wywiadów. Wydaje się, że uległ zmianie ich pierwotny stosunek do przeszłości oraz że zmieniło się emocjonalne zaangażowanie we własne świadectwo. Do pewnego stopnia wynika to oczywiście z odmiennego gospodarowania czasem na emeryturze, kiedy czas płynie wolniej i zostaje go więcej na zastanowienie i refleksję. $\mathrm{Na}$ dodatek widok dzieci i wnuków stale przypomina o własnej młodości, a jednocześnie rodzi możliwość odniesienia się do rodziców, z pełną świadomością, że osiągnęło się wiek, którego nie było im dane doświadczyć (Leon W.). Wiadomo też, że z punktu widzenia ludzi starszych rozróżnienie pomiędzy przeszłością i przyszłością staje się dużo mniej istotne. Tendencja ta niekoniecznie jest oznaką dezorientacji lub zaburzeń umysłowych. To raczej wiek powoduje przenikanie przeszłości w teraźniejszość, co jest rzadko spotykane u ludzi młodszych. Chociaż przeszłość wydaje się wypełniać większą część ich życia codziennego, sytuacja rodzinna ciągle stwarza im możliwość przepracowywania przeszłości na poziomie psychoemocjonalnym. 
We wcześniejszych wywiadach wydawało się, że ocalali czują się bombardowani przez jeszcze nieskontekstualizowane, potężne fragmenty swojej przeszłości, czego nie uświadamiali sobie w pełni w trakcie narracji. Wydawało się, że istnieje ryzyko naruszenia lub całkowitej utraty granicy pomiędzy ich przeszłością i życiem, które wiedli w czasie nagrywania świadectwa. Uczucia były dużo bardziej niespodziane, rozproszone i dezorganizujące, pozostawały oderwane od narracji i prawie niczego nie wnosiły do jej przebiegu lub kształtu.

Wspomnienia były w swojej bezpośredniości zniewalające, pełne ekspresji i przyćmiewały wszystko: belgijski więzień wymieniający swoją żywność na rację tytoniu tylko po to, żeby ją od razu wypalić, a potem pójść do latryny i się powiesić (Zoltan G.); przyjaciel podcinający sobie nadgarstki na krótko przed wyzwoleniem i ocalały świadek bandażujący mu rany i nie pozwalający mu umrzeć (Leon W.); przyjemność patrzenia, jak po wyzwoleniu jeden z niemieckich strażników zostaje zastrzelony przez więźniów (Leon W.) i radość na widok ciała esesmana zabitego podczas alianckiego bombardowania (Zoltan G.); matka mówiąca synowi, który mógł uciec z getta, porzucając swoją rodzinę: „Chodź z nami. Jeśli musimy umrzeć, umrzemy razem" (cała rodzina została zabrana do Auschwitz: Zoltan G.); gniew po wojnie, pragnienie zabijania bez końca (Zoltan G.).

Wydaje się, że w tych wcześniejszych narracjach czas się zatrzymał. Wszystko dzieje się jakby równolegle. Brakuje narracyjnej perspektywy, która pozwalałaby umieścić te wszystkie wydarzenia w przeszłości. Słuchacz odchodzi z poczuciem braku zakończenia: wszystko trwa nadal, jakby nigdy się nie zakończyło. Jednocześnie zauważalne jest silne wrażenie bezbronności opowiadających, które wypełnia ich narrację. Zdają się bombardowani fragmentami pamięci, przekazują swoje świadectwa pod olbrzymią presją, jakby biegli, uciekając przed tym ostrzałem. Wydaje się, że nie mają czasu; pędzą przez swoje doświadczenie, jakby starali się zminimalizować kontakt oraz uniknąć emocji i refleksji. Jakby zatrzymanie się, spojrzenie, zadanie pytania miało wznowić fatalny w skutkach krwotok. Trzeba by czasu całego życia, aby opowiedzieć te historie, a takiego czasu w ich życiu nie ma.

Pojawiają się liczne wzmianki o fizycznym wyniszczeniu, śmierci, zwłokach, zniknięciach, publicznym biciu i publicznym wieszaniu, ale uczucia przerażenia i żalu, których można by oczekiwać przy takich obserwacjach, pozostają zaledwie słowami, pozbawionymi emocjonalnego oddźwięku w doświadczeniu, do którego się odnoszą. Ocalali są świadomi swojego 
248 stanu oderwania i opisują, że przez większość swego prześladowania żyli w stanie odrealnienia. Czuli, że w rzeczywistości nic takiego nie może się im przydarzać. Żyli w zamroczeniu, w strefie mroku. Nawet wyzwolenie było nie-wydarzeniem: „Nie sądzę, żebym radował się tym, że przeżyłem”, powiedział Leon W., a kiedy został zapytany, co pomyślał w chwili swojego wyzwolenia, odpowiedział: „Jedzenie”. Dla niego głód był jedynym wszechogarniającym odczuciem, przytępiającym wszystko inne. Po wojnie to oderwanie trwało nadal. Wielu ocalałych mówiło o swoim równoległym życiu, o podwójnej egzystencji. Z jednej strony radzą sobie z funkcjonowaniem tu i teraz i żyją swoim życiem, chociaż bez widoku na radość; z drugiej strony ciągle są „z powrotem tam” i pozostają uwięzieni w przeszłości. Jak wyraził to Leon W. w swoim pierwszym wywiadzie, jest „zawsze coś z tyłu mojej głowy". Często brakuje chęci, aby stworzyć pomost między tymi równoległymi i osobnymi egzystencjami. Muszą być w ocalałych trzymane z dala od siebie, aby byli w stanie żyć.

Ten psychologiczny rozdział pomiędzy przeszłością Holokaustu i życiem, które sobie stworzyli po emigracji z Europy, widać wyraźnie w pierwszym świadectwie złożonym przez Zoltana G. Chociaż zostało ono zarejestrowane w jego domu, prawie niczego nie mówi o osobie, którą się stał od czasu wyzwolenia. Poza jego doświadczeniem Holokaustu nie istnieje punkt odniesienia, który zapewniłby tkankę łączną i stworzyłby kontekst dla jego narracji. Relacje pomiędzy nim i osobami prowadzącymi wywiad są bardzo ciepłe, ale u podstaw kryje się niepewność, czego oczekiwać, a właściwie niepewność co do oczekiwań obu stron. Wspomnienia, którymi dzieli się z prowadzącymi wywiad, następują po sobie jak dźwięki grane staccato. Zoltan G. opisuje swój strach, gdy jako Żyd pod węgierską okupacją bał się nawet przejść przez ulicę; jak został pobity przez żandarma; swój gniew na żydowskich rodaków, którym zabrakło dobrych rad silnych przywódców i kurczowo uczepili się życia z tak wielkim strachem, że nie chcieli podjąć ryzyka i stawić oporu; swoje poczucie wstydu w reakcji na taką pasywność; swoją izolację jako jednego z najmłodszych więźniów w Auschwitz; gniew i gorycz po wojnie; nienawiść do Niemców, którzy przed Holokaustem słynęli ze swojej edukacji. Często tym opisom trudnych odczuć towarzyszy uśmiech, który wydaje się dziwnie niestosowny wobec gwałtownych uczuć.

W nowszym wywiadzie starzejąca się twarz Zoltana G. też nosi ślady gniewu, a jego narracja nadal jest chwilami ozdobiona tym dziwnie niestosownym uśmiechem. Jednak jego uwaga w dużo mniejszym stopniu skupia się na opisie uczuć, które pozostają bez związku z teraźniejszością. 
Jego wspomnienie jest żywe i angażuje emocjonalnie, a chwilami porywa słuchacza z nieodpartą siłą. Szczególnie dotyczy to powracającej relacji o rzeczach, które jako więzień obozu jadł, aby przetrwać głód. Przypuszczalnie najmniej szkodliwym jedzeniem były gruszki, które skądinąnd brutalny esesman dawał młodemu Zoltanowi, aby nagrodzić go za dobrą pracę w służbie ogrodniczej Auschwitz-Landwirtschaft. Więźniowie jedli psy i koty, które Zoltan pomagał odzierać ze skóry. Kiedyś pomógł ubić konia i zatrzymał jedno z jego kopyt, które żuł tygodniami. Kiedy pomógł odrzeć ze skóry krowę, która złamała nogę, poślizgnąwszy się na oblodzonej ścieżce, zatrzymał duży kawałek surowego tłuszczu spod jej skóry i nosił go pod koszulą, aby ogrzewać klatkę piersiową i mieć coś do zjedzenia. Zdrapywał resztki buraków cukrowych ze ścian wagonu, którym pod koniec wojny razem z innymi więźniami był transportowany. W swoim pierwszym świadectwie wspomina już nieco o tym, co jadł, ale dopiero w nowszym wywiadzie znajdujemy narracyjne zagęszczenie jego głodu, co ukazuje zarówno okropieństwo wygłodzenia Zoltana G. podczas pobytu w obozach, jak i granice, do jakich jego i innych więźniów głód doprowadził. Chociaż to nieprawdopodobne menu może wywołać w słuchaczach przejmującą świadomość głębokiego empirycznego rozdziału, który odgradza ich od ocalałego i rzeczywistości, którą on wspomina, Zoltan G. przez cały wywiad pozostaje bardzo blisko siebie jako głodującego więźnia obozu i od czasu do czasu komentuje to, co jadł, słowami: „Było dobre”.

Jednak nasz rozmówca był nie tylko nadzwyczajnie świadomym młodym chłopakiem. Przybył na wywiad w towarzystwie swojej córki Vivian, która pod koniec nagrania, kiedy jej ojciec opisywał swoje życie po wojnie, karierę zawodową i rodzinę, którą zbudował, stała się bardziej aktywna. Ich relacja ujawniła całkowicie odmienną stronę Zoltana G.: było oczywiste, jak bardzo troszczy się o swoją córkę, z którą delikatnie i żartobliwie się przekomarzał. Oto człowiek absolutnie urzekający i urzeczony swoim potomstwem. Zoltan - kochający ojciec istniał ramię w ramię z Zoltanem - głodującym nastolatkiem.

Kolejnym przejawem emocjonalnej złożoności był jego stosunek do Niemców i Niemiec. Ponownie wspomniał nienawiść, którą czuł do Niemców zaraz po wojnie, kiedy uważał, że każdy z nich powyżej piątego roku życia powinien zostać zabity. Jednak również z dumą napomknął, że w szkole nauczył się staroniemieckiego pisma i że do dziś jest zakochany w języku niemieckim. W latach 90. XX w. odbył podróż do Niemiec, bardzo unikając ponownego odwiedzenia miejsc swoich prześladowań. Wydawało się, 
że nienawiść nie wpłynęła na jego zdolność kochania, a miłość nie zatarła jego nienawiści. Bez względu na sprzeczność współistniały one w tej samej osobie, która była w stanie połączyć to wszystko razem w jednej narracji.

W udzielonym niedawno wywiadzie Zoltan G. wyraźniej dotyka cierpienia i degradacji, które sprowadziło na niego doświadczenie bycia więźniem obozu. Być może z wiekiem zużywają się psychologiczne mechanizmy obronne, które zazwyczaj pomagają ego odrzucać kwestionujące i wyniszczające je idee i wydarzenia ${ }^{8}$. Dlatego jego narracja już nie jest skrywana za tarczą gniewu lub wyparcia i może się wyraźniej ujawnić jej zawartość emocjonalna, która mniej „współgra” z jego jaźnią (egosyntoniczną) i obrazem siebie (self-image) jako gniewnego bohatera, który zaryzykował życiem, aby wygrać walkę. Zoltan G. rzeczywiście był takim bohaterem, kiedy wkrótce po wojnie pojechał do Palestyny i walczył w izraelskiej wojnie o niepodległość. Jednak podczas gdy ta heroiczna postać wydaje się strażnikiem wcześniejszej narracji, w drugim wywiadzie narracja jest przezentowana przez starego człowieka, który może jedynie wspominać siebie jako bohatera. Nie oznacza to, że Zoltan G. znajduje się na granicy utraty kontroli nad swoją historią. Przeciwnie: wydaje się, że z wiekiem osiągnął biegłość, która umożliwia uzyskanie dużo bardziej szczegółowego narracyjnego obrazu jego przeszłości, jako części jego życia. Heroiczna postać ma w tej złożoności swój udział, ale już nie rządzi przedstawieniem.

\section{Zmieniająca się dynamika wywiadu}

Przesunięcia narracyjne mogą występować oczywiście również na skutek dynamiki wywiadu. Różnice można zaobserwować w wywiadach z tym samym rozmówcami, ale prowadzonych przez różne osoby. Jednak w naszym przypadku można je przypisać ewoluującej i zmieniającej się technice stosowanej przez tego samego prowadzącego wywiad (Doriego Lauba) w trakcie pracy ze świadectwami ocalałych z Holokaustu. Następne akapity opierają się wyłącznie na doświadczeniu Lauba, dlatego wypowiedziane są jego własnym głosem.

Na poziomie świadomości bardzo wyczekiwałem ponownego spotkania z ocalałymi, z którymi przeprowadziłem wywiady dwadzieścia pięć lat temu. Zadałem sobie trud, aby odnaleźć tych pierwszych świadków i nawiązać

A. Freud, The Ego and the Mechanisms of Defense, [w:] eadem, The Writings of Anna Freud, I-VIII, t. II, New York 1966 (wyd. I: 1936). 
z nimi kontakt. Byłem przekonany, że przez te lata nasze relacje w dużym stopniu się utrzymały, a nawet, w domyśle, rozwinęły. Ku mojemu całkowitemu zaskoczeniu zdałem sobie sprawę, że zupełnie zapomniałem o czterech z ośmiu ocalałych, których jeszcze udało mi się odnaleźć, chociaż przez te lata raz po raz spotykałem ich przy pełnieniu funkcji społecznych, szczególnie podczas uroczystości upamiętniających. Co więcej, nawet gdybym ich pamiętał, zapomniałem większość ich histori i przypomniały mi się one, dopiero kiedy zaczęli mówić. W jednym wypadków (Zoltan G.) byłem nieświadomy, że już spotkałem tego ocalałego i dopiero po naszym wywiadzie z jesieni 2005 r. odkryłem, i to przypadkiem, dzięki katalogowi Fortunoff Video Archive, że prowadziłem z nim wywiad dwadzieścia siedem lat wcześniej.

Doświadczenie bieżącej dialogicznej relacji oraz ekscytacja i oczekiwanie ponownego spotkania są nieodłączną częścią samego procesu składania świadectwa. Procesy zaświadczania, rozmyślania i autorefleksji raz wprawione w ruch, stale nabierają rozpędu i własnego życia. Ponowne spotkanie w związku ze świadectwem nie tylko wydawało się potęgować te procesy, ale też posłużyło jako moment podsumowania pracy, która dotąd została wykonana. Ocalały i ja byliśmy partnerami w tych procesach. Jednak tylko tak dalece mogłem świadomie być pośrednikiem dla tego, co mi mówili. Musiałem uwolnić się od ich historii, aby móc żyć dalej. Moje zapominanie było oporem i samoobroną przed tym, co w narracjach ocalałych było dla mnie emocjonalnie obezwładniające, niezrozumiałe i przerażające. Zapominanie było moją startegią chronienia siebie przed własnym rozpadem.

Niedawne wywiady potwierdziły moje przeczucie, że nasze relacje trwały na poziomie utajonym. Chociaż ja o nich zapomniałem, oni nie zapomnieli o mnie, a poczucie zażyłości, podjęcia na nowo wątku, było natychmiastowe. Mieliśmy wrażenie, że skończyliśmy wczoraj, a teraz tylko możemy pociągnąć ich historie trochę dalej, trochę głębiej. Chociaż tym razem również nie mieliśmy poczucia zakończenia lub domknięcia, wiedzieliśmy, że z wszelkim prawdopodobieństwem jest to ostatnie w naszym życiu spotkanie tego rodzaju.

Słuchając siebie na taśmie jako prowadzącego wywiady ponad dwadzieścia pięć lat temu, zdaję sobie sprawę, jak w tych pierwszych wywiadach unosi mnie strumień, intensywność, bezpośredniość, prawie namacalność fragmentów pamięci moich rozmówców. Nie miałem wówczas pytań, które pomogłyby spowolnić ich narrację lub wzbogacić i pogłębić opis ich doświadczenia. Nawet kiedy zadaję pytania, wydaje się, że odnoszą one 
252 niewielki skutek. W tamtym momencie trwa bombardowanie ich pamięcią i nie mogę go powstrzymać. Jestem niezdolny do ingerencji, do bycia obecnym, do zdecydowanego tworzenia bezpiecznej przestrzeni dla ich świadectwa. Aż nadto często jestem owładnięty poczuciem bliskości wydarzeń, które opisują. Niewiele jest chwil ciszy, niewiele podejść do wewnętrznego „ja”, niewiele enklaw autorefleksji. Nie chcąc i wbrew własnym intencjom prowadzącego wywiad, współdziałam ze zranieniem i bezbronnością ocalałych. Obie strony wydają się tak bardzo przerażone ich wspomnieniami, że nie jesteśmy w stanie zbyt długo się przy nich zatrzymać. Ja sam też wpadłem w pośpiech przez to, że zaplanowałem zbyt wiele wywiadów i ułożyłem je w harmonogranie zbyt blisko siebie. Potrzebowałbym miesięcy, jeśli nie lat, aby powstał we mnie jakiś empatyczny fundament, dzięki któremu mógłbym zbudować roboczą więź, pomagać otwierać perspektywy i stworzyć ramę, która pomieści introspekcję i autorefleksję.

Ta retrospekcja wynika oczywiście ze zrozumienia procesu prowadzenia wywiadu, które nabyłem przez dziesiątki lat pracy. Jako prowadzący wywiad musiałem wyrobić sobie postawę empatycznego słuchacza. „Świadectwo jest apelem narracji, aby jej wysłuchać: bo tylko kiedy ocalały wie, że jest słuchany, zatrzyma się, aby usłyszeć - i posłuchać - siebie”’. Przyjmując postawę „innego", którego słuchanie umożliwia process narracyjny, zacząłem myśleć o sobie jako o towarzyszu w pełnej grozy podróży świadectwa, jako „ktoś, kto w rzeczywistości uczestniczy w ponownym przeżywaniu i doświadczaniu wydarzenia"10. Słuchanie nie jest więc jedynie receptywne i pasywne, lecz przeciwnie, jest w pełni zaangażowane i aktywne. Paradoks tkwi w tym, że prowadzący wywiad musi być dyskretnie obecny, to znaczy musi pośredniczyć, ale nie być bezpośrednio obecnym. Z braku lepszego określenia, zasugerowałem, że istnieje - z psychoanalitycznego punktu widzenia - „potrzeba olbrzymiego intymnego zaangażowania w sytuację wywiadu $\mathrm{z}$ ocalałymi: opisywane jest tyle zniszczenia, tyle śmierci, tyle ofiar, tyle rozpaczy, że aby podtrzymać narrację konieczne jest maksimum bliskości i emocjonalnego zaangażowania"11.

D. Laub, Bearing Witness or the Vicissitudes of Listening, [w:] S. Felman, D. Laub, Testimony: Crises of Witnessing in Literature, Psychoanalysis, and History, New YorkLondon 1992, s. 57-74, tu: s. 71.

D. Laub, An Event without a Witness: Truth, Testimony, and Survival, [w:] S. Felman,

D. Laub, Testimony..., s. 75-92, tu: s. 76.

D. Laub, Bearing Witness..., s. 71. 
Zdolność utrzymywania przez osobę prowadzącą wywiad bliskości, stwarzającej bezpieczną przestrzeń i zapewniającej kontekst, w którym rozmówcy mogą pozwolić swoim wspomnieniom się wyłonić, przejawia się na różne sposoby. Kiedy podczas niedawnego wywiadu z Ralphem F. zdałem sobie sprawę, że nie będzie on w stanie zrelacjonować swojego doświadczenia pod niemiecką okupacją we wschodniej Polsce inaczej, niż czytając pisemne oświadczenie - można było się domyślać, że przeżył własną egzekucję i wykopał się z masowego grobu - spróbowałem nakierować narrację na twardy grunt, na którym mógł ukazać siebie jako partyzanta i żołnierza, który ostatecznie dotarł z Armią Czerwoną do Berlina. Musiałem przywrócić rozmówcy poczucie bezpieczeństwa, nawet jeśli uniemożliwiło to bardziej szczegółową narrację, ponieważ groziło mu załamanie się pod ciężarem wspomnień, chociaż nigdy całkiem nie wyjaśniło się, czym był ten ciężar.

Kolejny trudny moment, który może być dobrą ilustracją mojej bliskiej obecności jako osoby prowadzącej wywiad, tym razem podtrzymującej ciągłość w chwili przerwy, pojawił się podczas wywiadu z Leonem W. w ramach „Forced and Slave Labour Project”. Dla Leona zdecydowanie najbardziej bolesnym doświadczeniem był powojenny powrót do rodzinnego miasta, Łodzi, w nadziei odnalezienia tam rodziny. Czekał na ich powrót przez cztery do pięciu miesięcy. Nikt nie wrócił. Podczas gdy w swoim pierwszym świadectwie wspomina dramat rozczarowania i to, jak przez kilka lat, bez jakiegokolwiek planu lub poczucia kierunku, przechodził przez różne obozy dla przesiedleńców w Niemczech, w drugim wywiadzie załamuje się: przez moment ogarnia go groza wejścia do pustego rodzinnego mieszkania. Jest przytłoczony i wybucha płaczem. Pomimo jego protestów, że ma już dość i gestów mówiących o tym, że chce wyjść, kontynuuję wywiad. Wiem, że on także chce pozostać i odzyskać samokontrolę. Jeśli teraz wyjdzie, nasze obustronne wysiłki skończą się porażką. Obaj będziemy czuć się całkowicie rozbici, opuszczeni i zagubieni. Zabrało to kilka minut, ale odzyskał nad sobą panowanie i przez jakiś czas kontynuował narrację.

Wywiad nie tylko uwolnił ból związany z utratą rodziny, ale także pozwolił Leonowi W. wyjść poza niego. Kontynuacja narracji została wsparta bliską obecnością empatycznego słuchacza, który potrafił wczuć się w ból rozmówcy, a jednocześnie umacniał ocalałego, aby był on w stanie kontynuować narrację i aby nie przytłoczyła go przeszłość. Tak więc rama jego narracji pozostała zespolona i nie załamała się, chociaż odchylenie wahadła emocji było dużo większe i bardziej dramatyczne. Tym razem Leon W. nie pominął swoich doświadczeń i uczuć. W nowszym świadectwie wiele drobniejszych 
254 szczegółów z pierwszego wywiadu schodzi na dalszy plan i staje się mgliste, ale jego rama przynosi wyraźną ulgę. Przesłanie, które chce on przekazać, jest jasne: wie, czego dotyczy jego ból.

\section{Konkluzja}

Świadectwo wyłania się jako forma dialogiczna w procesie interpersonalnym - narracja ocalałego może pojawić się tylko w obecności słuchacza. Dla rezultatu wywiadu kluczowa jest więc postawa prowadzącej go osoby, a nieznaczne zmiany tej postawy mają olbrzymie znaczenie. Prowadzący wywiad może bezwiednie stać się wspólnikiem rozmówcy lub działać jako jego odpowiednik i pośrednik, który jest zdolny do okazania emocjonalnej siły, potrzebnej, aby być obecnym w obliczu lęku, żalu, gniewu lub upokorzenia.

W świadectwach składanych w różnych momentach (historii, jak też życia jednostki) strumień pamięci wydaje się przyjmować różny kształt. Podczas gdy pierwsze świadectwa charakteryzują się pewną surowością i czerpią siłę ze skoncentrowania się na czymś, co pozostaje odizolowane i oderwane od reszty życia rozmówcy, nowsze świadectwa odsłaniają więcej szczegółów i zawierają znacznie więcej różnorodnych dużo szerszy wachlrz przeżyć i emocji. Jakby wraz ze zbliżeniem się do końca życia świadek zyskał większą zdolność panowania nad emocjami, co umożliwia dużo bardziej zniuansowaną i intensywną złożoność, wewnętrzny konflikt i sprzeczność. Ważne w życiu postacie - rodzice, przyjaciele, ukochane rodzeństwo - stają się trójwymiarowe, mają wyraźne osobowości. Doświadczenie jest bardziej spójne i zróżnicowane. Pozycja wyjściowa do obserwacji i autorefleksji jest znacznie bardziej zespolona i ciągła. To, co na początku wcześniejszych wywiadów było po obu stronach - rozmówcy i osoby prowadzącej wywiad - niepewnością oczekiwań wobec siebie i drugiego, stało się przedmiotem pewności i wiary w siłę raz uruchomionego procesu składania świadectwa.

Oprócz tej różnicy w stosunku do świadectwa, która zdawała się wynikać z etapu życia rozmówców, należy również uwzględnić zmieniający się kontekst historyczny, w którym każdy wywiad miał miejsce. Historycy i badacze zyskali w obecnych czasach dużo więcej wiedzy $\mathrm{i}$ - w porównaniu z latami 7o. i 8o. XX w. - większa jest społeczna świadomość Holokaustu. Przez minione dwadzieścia pięć lat „Holokaust” został skonceptualizowany jako wydarzenie historyczne. W kontekście takiej nadrzędnej narracji jest bardziej prawdopodobne, że rozmówcy zrozumieją i wysłuchają siebie, jako ocalałych. Wczesne i niedawne wywiady dokumentują ten postęp, który 
ułatwiły w międzyczasie ich świadectwa. Te dwa zbiory wywiadów wspierają proces, który można opisać jako ewolucję świadectwa.

Na koniec należy podkreślić, że wraz z tymi przesunięciami i zmianami odkryliśmy w wywiadach godną podziwu spójność. Nie pojawiły się żadne rażące sprzeczności. Nie było praktycznie żadnego dowodu na to, że pamięć z czasem się zatarła. Były to raczej dwie historie opowiedziane w odstępie ponad dwudziestu pięciu lat z olbrzymią zbieżnością, uzupełniające się i składające się na jeszcze pełniejszy opis doświadczenia. Wydaje się, że dwadzieścia pięć lat introspekcji, słuchania siebie i innych oraz „życia” pozostawiło swój niezatarty ślad na ocalałych z Holokaustu, którzy, można by rzec, weszli w "przymierze składania świadectwa”, chociaż prawdopodobnie nie przybliżyło ich to do pogodzenia się ze swoim doświadczeniem. 